\title{
TOKENS OF RESENTMENT: MEDIEVAL ARABIC NARRATIVES ABOUT GIFT EXCHANGE AND SOCIAL CONFLICT
}

\author{
Jocelyn Sharlet \\ UNIVERSITY OF CALIFORNIA, DAVIS
}

Stories about gift exchange can confirm individual relationships and communal bonds, but they can also articulate social conflict. This analysis focuses primarily on stories in the first of two extant monographic compilations on gift exchange, the tenth-century Book of Rarities and Gifts by the Khālidiyyān, and concludes with a story from the anonymous eleventh-century Book of Treasures and Rarities. It explores expressions of social conflict through the features of rhetorical focal points, silence, communication at a distance, and the incongruity between fine gifts and tense situations. The discussion examines social conflict by following the development of main characters in other stories. These features of gift exchange stories suggest an interest in emotional experience, and the relationships among different stories about the same person imply an interest in character development. The pleasant practice of gift exchange offers a counterpoint to and a commentary on social conflicts.

Gift exchange stories in medieval Arabic literature appear as part of a broader interest in exploring social life through the intersection of refined rhetoric and material wealth. The topics of avarice, partycrashing, the figure of the Bedouin, the genre of the maqama, and stories about the patronage of panegyric poetry also revolve around the intersection of refined rhetoric and material wealth. Gift exchange has received less attention than these topics in modern research although it is a significant theme in medieval Arabic literature. This analysis focuses on stories in the first of two extant monographic compilations on gift exchange, The Book of Rarities and Gifts by the Khālidī Brothers, who lived in the 4th/10th century in Iraq and Syria. ${ }^{1}$ It concludes with a story

1 Abū Bakr Muhammad b. Hāshim al-Khālidī died in 380/990 and Abū ${ }^{\mathrm{c}}$ Uthmān Sa ${ }^{c} \overline{1} \mathrm{~d}$ b. Hāshim died in 390/999. According to their poetry, they moved from Khālidiyya to Mosul, and then to Baghdad, Aleppo and Damascus. (Abū Bakr Muḥammad and Abū 'Cthmān Sa ${ }^{c} \bar{i} d$ al-Khālidiyyān, Dīwān al-Khālidiyyān, ed. Sāmī al-Dahhān (Beirut, 1992/1412), pp. 9-20). Unlike some poets of their time, they were more interested in composing poetry for pleasure than for patrons (alKhālidiyyān, Dīwān, p. 25). They were connected to Sayf al-Dawla 337/948- 
from the second of the two extant monographs, The Book of Treasures and Rarities by an anonymous author who lived in the 5th/11th century in Egypt. ${ }^{2}$ It also investigates other stories about characters in the stories that are the focus of the discussion, and that complement those gift exchange stories.

As in most narratives in medieval Arabic prose literature, gift exchange stories are brief and often feature historical characters. Rhetorical focal points amplified by silence, the motif of communication at a distance in writing, and the jarring contrast between pleasant gifts and tense situations within individual stories, as well as the implied comparison and contrast of gift exchange stories with other stories about the same characters, enable writers to depict the complexity of characters and their relationships. In particular, gift exchange stories offer a diversion from, and a commentary on, a range of social tensions and conflicts. They complement other stories about the same characters that also explore these tensions and conflicts. Characters take shape in gift exchange stories, and in related stories, as figures of these broader social issues.

Gift exchange stories often involve historical characters with historical events in the background. The combination of the determinate quality of reality and the indeterminacy of the imaginary, involving selection and

346/957, for whom they worked as librarians, and to al-Muhallabī and especially Abū Ishāq al-Ṣābī 349/960-352/963 (Abū Bakr Muhạmmad and Abū 'CUthmān Sa $^{c} \overline{1} \mathrm{~d}$ al-Khālidiyyān, Kitāb al-Tuḥaf wa-l-hadāyāā, ed. Sāmī Dahhān, Cairo, Dār al$\mathrm{ma}^{\mathrm{c}} \overline{\mathrm{a}} \mathrm{rif}, 1956$, p. mìm). Patronage is mentioned in the book of gifts, but it is not clear to whom it was dedicated.

2 The editor of the Dhakhā ir proposes that the author is the Qādī Ibn Zubayr, who worked for the Buwayhids and then lived in the fifth century in Egypt, based on a comparison of some passages with the eighth-century adab collection by alGhuzūlī (Kitāb al-Dhakhā̄ir wa-l-tuhaf, ed. Muḥammad Ḥamīd Allāh, Kuwait, 1959, pp. 12-3). The translator argues that this attribution is not convincing because other passages that are parallel in the two works are attributed to three other authors. Instead, she explains that internal evidence in the book shows that the author was probably a Fatimid official who was in Cairo 444/1052-463/1070 (Book of Gifts and Rarities, tr. Ghāda al-Hijjāwī al-Qaddūmī, (Cambridge, Massachusetts, 1996), pp. 12-3). The author uses oral and written sources, but not the Khālidīs' book, although there are several parallel passages in the two works (Gifts, pp. 17 and 24). 
combination, can occur in texts that mask their fictionality, not for the purpose of deceit, but to offer an explanation of the world that would not otherwise be effective. ${ }^{3}$ Mimesis in work by al-Jāhiz is based on the imaginary as well as verisimilitude with reality, and other prose writers follow him in valorizing the combination of reality and fiction for literary, philosophical, and ethical ends. ${ }^{4}$ Verisimilitude can be understood as a public consensus on reality. ${ }^{5}$ The imaginary dimension of public consensus is a built-in feature in the real. Stories with historical characters and events allow the audience to contemplate experience, historical and contemporary, from different angles, and possibly change the course of their own experiences in response. ${ }^{6}$ Gift exchange stories thus provide responses to the question of how adab relates to politics. ${ }^{7}$

3 Wolfgang Iser, The Fictive and the Imaginary: Charting Literary Anthropology, (Baltimore, 1993), p. 12.

4 Ibrahim Geries, "L'adab et le genre narratif fictif" in Stefan Leder, ed., Story-telling in the framework of non-fictional Arabic literature (Wiesbaden, 1998) pp. 168-95, pp. 170, 195.

5 Tzvetan Todorov, The Poetics of Prose, tr. Richard Howard (Ithaca, 1977), p. 82 .

6 Similar techniques are used in the configuration of sequences of events in narratives that are found in texts that are thought of (then and now) as literary and texts that are thought of as historical (Robert Hoyland, "History, fiction and authorship in the first centuries of Islam" in Julia Bray, ed., Writing and Representation in Medieval Islam: Muslim horizons, (London, 2006) pp. 1646). Writers craft stories with historical characters and events in a range of ways. See Julia Bray, "Figures in a Landscape: The Inhabitants of the Silver Village", in Leder, ed., Story-telling, pp. 79-93; Julia Bray, "Tanūkhī’s alFaraj $b a^{c} d$ al-shidda as a Literary Source", in Alan Jones, ed., Arabicus Felix: Luminosus Britannicus (Oxford, 1991, pp. 108-28); Andras Hamori, "Exemplum, Anecdote, and the Gentle Heart in a Text by al-Jahshiyārī", Asiatische Studien 50/2 (1996), pp. 363-70; Andras Hamori, "Tinkering with the Text: Two Variously Related Stories in the Faraj Bac $d$ al-Shidda" in Leder, ed., Story-telling, pp. 61-78; Letizia Osti, "Al-Qāsim b. ' Ubayd Allāh, the Vizier as Villain: On Classical Arabic Gossip" in James E. Montgomery, ed., ${ }^{c}$ Abbāsid Studies: Occasional Papers of the School of 'Abbāsid Studies (Leuven, 2004, pp. 233-47; Ulrich Marzolph, "Arabische Witze als Quelle für die materielle Kultur" in Ex Oriente Fabula: Beiträge zur Erforschung der narrativen Kultur des islamischen Vorderen Orients, 2 vols. (Dortmund, 2005), $1: 134-52$.

7 Julia Bray poses and discusses this question (Bray, Julia, "c Abbasid myth and the Human Act: Ibn 'Abd Rabbih and others" in Kennedy, ed., On Fiction and 
These stories are part of an expanding cultural sphere in which poets and writers define a world apart from politics that is also very much in, and of, the political sphere. They seem like a re-use of historical characters and events; and a re-use of cultural production may be a way to resist hegemonic sites of cultural activity. ${ }^{8}$ However, gift exchange stories do not so much as resist the serious moral and historiographical inquiry that circulates about major events and issues, as they represent a kind of "adabification" of that serious inquiry. ${ }^{9}$

In this process of adabification, gift exchange may be both a diversion from and a feature of social tensions and conflicts. As Marcel Mauss has shown, communities embed the exchange of material gifts in social life so that gifts establish and maintain communal bonds, and so that the refusal to engage with others through gift exchange is tantamount to aggression. ${ }^{10}$ Similarly, a miser's refusal to interact with others through generosity displays his alienation from social life.${ }^{11}$ Failed gift exchange

Adab in Medieval Arabic Literature, Wiesbaden: Harrassowitz, 2005, pp. 1-50, pp. 48-9). It is also discussed in Abdallah Cheikh-Moussa, "L'Historien et la literature Arabe medieval" Arabica 43 (1996), pp. 152-88.

${ }^{8}$ Michel de Certeau, The Practice of Everyday Life, tr. Steven Rendall (Berkeley, 1984), p. 18. Muhsin al-Musawi views nonverbal elements in the Thousand and One Nights, including material objects, as nonverbal narratives that work in collaboration with the verbal narrative or as an offsetting practice (Muhsin J. al-Musawi, "Scheherazade's Nonverbal Narratives", Journal of Arabic Literature 36/3 (2005), pp. 338-62, pp. 338 and 340).

9 Andras Hamori, "Prudence, Virtue, and Self-respect in Ibn al-Muqaffa" in Angelika Neuwirth and Andreas Christian Islebe, eds., Reflections on Reflections: Near Eastern Writers Reading Literature (Wiesbaden, 2006), pp. 161-80, p. 175; he uses "adabization" and I seem to have changed the term inadvertently; it is the same idea. "Ababification" in this sense is an eclectic elaboration on characters and events that had already appeared in earlier texts, and it offers new perspectives on those characters and events.

10 Marcel Mauss, The Gift: The Form and Reason for Exchange in Archaic Societies, tr. W. D. Halls (London, 1990). Samī al-Dahhān observes that adab chapters on gift exchange usually begin with citations of the Qur'an and hadithbut not in the book by the Khālidī brothers (Al-Khālidiyyān, Tuhaf, p. 13). The religious sources on gift exchange are beyond the scope of this project.

11 Daniel Beaumont, "Min Jumlat al-Jamādāt: The Inanimate in Fictional and Adab Narrative" in Philip F. Kennedy, ed., On Fiction and Adab in Medieval Arabic Literature (Wiesbaden, 2005), pp. 55-68 (p. 65). 
can display social problems; in addition, gift exchange that takes place can convey tensions and conflicts. One critic observes that Mauss sometimes asserts that the material gift is embedded and expressive of social relations, and sometimes denies any real difference between the disembedded exchange of goods, as in a typical modern economy, and the embedded exchange of goods in the more traditional economies that Mauss discusses. ${ }^{12}$ This ambivalence about the social and ethical versus the material value of the gift appears in many chapters or selections on gifts in medieval Arabic literary culture. The ambivalence about gift exchange parallels the anxiety about the professional use of panegyric poetry. ${ }^{13}$

The material gift is packaged in refined rhetoric within the story and in the broader range of notices, stories, and poems relating to the characters that appear in the story. ${ }^{14}$ Long narratives play a relatively marginal role in medieval Arabic literature. ${ }^{15}$ While the individual stories, notices, and poems relating to a particular person are often short, the extended family of texts can be quite large. Although long narratives were relatively marginal in medieval Arabic literature, biography-a genre that delineated individual and communal identity and that both documented and shaped conflicts within and between groups-was absolutely central. ${ }^{16}$ Families of texts about a particular person, whether situated in biographical or other kinds of compilations, can convey the complexity of characters, character development and the concatenation

12 Scott Cutler Shershow, The Work and the Gift (Chicago, 2005), pp. 96-114.

13 Jocelyn Sharlet, Patronage and Poetry in the Islamic World: Social Mobility and Status in the Medieval Middle East and Central Asia (London, forthcoming 2010), chapters one and eight.

14 In addition to gift exchange poetry, which became established among tenth century poets who worked with or near the Khālidī brothers, gift exchange is featured in a number of chapters of $a d a b$ compilations (for a summary of their contents, see Jocelyn Sharlet, "The Thought that Counts: Poetry about Gift Exchange by Kushājim, al-Șanawbarī, and al-Sarī al-Raffāo", Middle Eastern Literatures, forthcoming 2011, note 6).

15 Jaakko Hämeen-Anttila, "Development of Arabic Prose from around A.D. 1000 to 1150 A.D." in S. Leder et al., eds., Studies in Arabic and Islam (Leuven, 2002), pp. 205-16.

16 Michael Cooperson, Classical Arabic Biography: The heirs of the prophets in the age of al-Ma mun (Cambridge, 2000). 
of events in sequence as if in a long narrative. ${ }^{17}$ Instead of the heteroglossia of a long narrative, families of texts offer a range of voices and perspectives on social tensions and conflicts by way of particular characters. ${ }^{18}$ This discussion investigates gift exchange that draws attention to the issues of the wrong words and the right gifts, rhetoric and relationship problems, political conquest, aggression and social tensions, and political crises, and further explores these issues in other stories about the characters involved in gift exchange.

The wrong words and the right gifts

Flawed rhetoric is the focus of the following two gift exchange stories. The flawed rhetoric entails a risk of failure of the gift exchange and the relationship that it expresses. However, the flaw in the rhetoric leads to a more abundant gift. In the first example, a friend of the Umayyad and then Abbasid general $\mathrm{Ma}^{\mathrm{c}} \mathrm{n}$ b. Z $\overline{\mathrm{a}}^{\supset}$ ida (d. 152/769), who was killed fighting the Khārijī opposition movement, wrote to him at his post in a province of Azerbayjan, "If the commander sees fit, please order for me a mount, for I am without a mount." $\mathrm{Ma}^{\mathrm{c}} \mathrm{n}$ wrote back, ordering for him a whole series of mounts, both male and female of each category, whether of body or in grammatical gender of the word, including female and male horses, mules, donkeys, camels, a cow and a bull, a ship and a boat, female and male slaves, and slippers and sandals, and expressing his hope to send elephants in the future. ${ }^{19}$ Conversely, in another story, a man wrote to a generous secretary of the Barmakid politicians, asking for a gift of a female slave in a description that is absurdly detailed in its elaborate use of rhetoric. The secretary wrote back that to the effect that he tried to find such a person and failed, but was sending a thousand gold coins so that the man can look for her himself. He promised to send the

17 See for example Antonella Ghersetti, “L'Anecdote-accordéon ou comment adapter le sense du récit au contexte narratif" and Abdallah Cheikh-Moussa, "Mouvance narrative et polysémie dans la littérature d'adab : le cas d'Abū Hayya al-Numayrī/Abū Aġarral-Nahšalī’ in Frédéric Bauden, Aboubakr Chraïbi, and Antonella Ghersetti, eds., Le Répertoire Narratif Arabe Médiéval: Transmission et Ouverture (Liège, 2008).

18 M. M. Bakhtin, "Discourse in the Novel", in The Dialogic Imagination, ed. Michael Holquist, tr. Caryl Emerson and Michael Holquist (Austin, 1981), pp. 259422.

19 Al-Khālidiyyān, Tuhaf, pp. 104-5. 
full price when she is found. ${ }^{20}$

In these brief stories, the prospective patron takes advantage of the wrong rhetoric in the request to demonstrate his munificence. The request that is too vague leads to a broad interpretation and every possible gift, and the request that is too detailed leads to a down payment and a blank check to cover the slave who is sought in excessive detail. These stories show that patrons enjoyed the factor of surprise and the unexpected. ${ }^{21}$ The factor of the unexpected helps writers to make patronage exchange into stories.

It does not really matter in the first story that the general was talented and successful, and was killed defending the imperial frontier. Likewise, in the second story, it does not matter that the Barmakids and their allies were one of the most powerful administrations in Islamic history and were purged in one of the major dramas of medieval Arabic literary culture. Instead, these stories show that when they were not busy defending the empire or managing its finances, $M^{c} n$ b. Za $\bar{a}^{-}$ida and the Barmakids' allies demonstrated their refinement. The comic yet lucrative outcomes of underdoing it and overdoing it in flawed rhetoric are comedies of manners that are integral to, yet distinct from the more serious business of politics.

Rhetoric and relationship problems in gift exchange

The writers in each of the following three short gift exchange stories use rhetoric that foregrounds the writer's difficulties. As in the flawed rhetoric gift exchange stories about $\mathrm{Ma}^{\mathrm{c}} \mathrm{n}$ b. Z $\overline{\mathrm{a}}^{ } \mathrm{ida}$ and the Barmakids' secretary, in these stories of the writer's difficulties, a surfeit of gifts bursts out of the boundaries of the rhetoric in which it is packaged. The amplification of the material gift in the course of the brief story is set against the backdrop of the characters' professional relationship problems. The clever turn of a phrase or apt use of fine verses serves as the rhetorical basis for the amplification of the gift, as well as a reference to relationship complications. ${ }^{22}$

20 Al-Khālidiyyān, Tuhaf, pp. 101-4.

21 Beatrice Gruendler, "Meeting the Patron: An Akhbâr Type and Its Implications for Muhdath Poetry" in S. Günther, ed., Ideas, Images, Methods of Portrayal: Insights into Arabic Literature and Islam (Wiesbaden, 2005), pp. 59-88.

22 Fine rhetoric may be a theme in its own right in addition to its use as a medium for the story (Andras Hamori, "Going Down in Style: The Pseudo-Ibn Qutayba's Story of the Fall of the Barmakīs", Princeton Papers in Near Eastern 
In the first story, the leading musician Ishạa b. Ibrāhīm al-Mawșilī presented a note that he received from the member of the imperial family and musician Ibrāhīm b. al-Mahdī on the occasion of Ishāà's son's circumcision. In the note, Ibrāhīm apologized for falling short of what was expected of him. He explained that he would hate to be left out of the gift-giving, so he is sending a measure of salt and a measure of soap. Ishạa continued, "Then gifts from him that are beyond description came to me". 23 The initial gift is too modest, but is amplified by the polite message that acknowledges the occasion, Ibrāhīm's obligation, and the need for a more substantial gift. The polite message gives way to Ishāā's concluding statement about the surfeit of gifts that followed. The message is like a catalyst that calls attention to the fact that the gift is too small, and also brings on the surfeit of gifts, which bursts out of the bounds of rhetoric. The gifts cannot be expressed in language.

The gift exchange story occurs in the context of tales about the tense yet collegial relationship between the professional musician Ishāa $b$. Ibrāhīm al-Mawșilī and the aristocrat and amateur musician Ibrāhīm b. al-Mahdī. The latter (d. 224/838) served as caliph for a short time and went into hiding after the army revolted. He was imprisoned and pardoned, and returned to court life where he became known for his life of music and poetry. As an amateur musician, Ibrāhīm was part of a significant trend of political elites participating in refined cultural activities for which they had once been only an audience. ${ }^{24}$ On the other hand, Ishāa (d. 235/849) was a leading professional musician and also the son of a leading musician. They promoted different styles of music and became intense rivals. In spite of their rivalry, Isḥāq b. Ibrāhīm alMawșilī and Ibrāhīm b. al-Mahdī sometimes appear as parallel characters in stories about refined manners and elegance. ${ }^{25}$

Stories about Isḥāq and Ibrāhīm often combine rivalry and refinement. In a story that emphasizes the tension between them, Ishāa and Ibrāhīm argued while the caliph al-Rashīd was out of the room. Ibrāhīm insulted Isḥāq, and Isḥāq said that he would insult Ibrāhīm if he were not from

Studies 3 (1994), pp. 89-125).

23 Al-Khālidiyyān, Tuhaf, p. 120.

24 J. E. Bencheikh, "Les musiciens et la poésie. Les écoles d'Ishāa alMawșilī (m. 225 H.) et d'Ibrāhīm Ibn al-Mahdī (m. 224 H.)", Arabica 22/2 (1975), pp. 114-52 (p. 131).

25 Antonella Ghersetti, "Musiciens, parasites et amoureux: le récit du 'Mariage d'Isḥāq"”, Quaderni di Studi Arabi nuovo serie 1 (2006), pp. 113-28. 
the royal family. Ibrāhim complained to the caliph, who got the story from the servants, and told Ibrāhīm to drop it. The caliph spoke privately to Isḥāq after the gathering and said, "Do you really think I would ever stand up for you in opposition to my own family member? If he had his slave boys kill you, do you think I would kill him for it?!" He summoned Ibrāhīm next, and Ishạā, who was beloved by servants, told them to let him know what was said. The next day, he learned that the caliph told Ibrāhīm, "Who do you think you are, treating my servant, protégé, and drinking companion, the son of my drinking companion, servant, and protégé, that way in my gathering? What do you know about singing, and what do you know about what he is? What makes you think you could equal him, when he's a professional through and through? So help me God, if anything happens to him, I'll kill you." The next time the caliph hosted them together, he had them make amends. ${ }^{26}$

Gift exchange complements patronage, and one story expresses the collegial rivalry in terms of the uncertainties of patronage. Ishāa relates a story in which Ibrāhīm complained to Isḥāq that he did not give him enough affection or stop by often enough. Isḥāq said, "I'll visit day and night just like I perform the five prayers, and then I'll skip some [just as I skip some of the prayers]." Ibrāhīm laughed and said, "Who can match singers!" Ishāa responded, "Someone who takes singing for himself and no one else." Ibrāhīm laughed again and gave him a servant, a mount, money, and a robe. Al-Mu'tașim heard the story and gave Ibrāhīm double that. ${ }^{27}$ Just as the gift exchange problem leads to a surfeit of gifts in the wake of Ibrāhīm's brief but apt message, this patronage complication gives way to a surfeit of gifts due to a clever verbal exchange.

In the second of these three short gift-exchange stories that feature the writer's difficulties, a generous and refined secretary of al-Șaffār (perhaps $\mathrm{Ya}^{\mathrm{c}} \mathrm{qu} \mathrm{u}$ b. Layth, the provincial ruler in Iran) had an elegant poet among his companions. The secretary's friends gave him some large gifts for the Persian New Year's holiday, Nowruz. The poet was impoverished. The secretary asked him for some gifts, saying, "You

26 Al-Baghdādī, Tārīkh Baghdād, 5:306. The narrator of one story explains that Ibrāhīm used to hound musicians until Isḥāq showed up, and that Ibrāhīm used to bait him but he wouldn't fall for it, so that Ishāq was his undoing (Abū l-Faraj alIṣfahānī, Kitāb al-Aghān̄̄, 27 vols., ed. 'Abd A. 'Alī Muḥannā and Samīr Jābir, Beirut, 2002/1422, 5:302).

27 Al-Ișfahān̄i, al-Aghānī, 5:329. 
have to give me something." The poet said that he would. He bought a lot of roses and wrote a poem to go with them that described the roses as the cheeks of Greek slave girls drinking wine, a glass of wine like a moon circulating in the hand of the wine pourer, and a general sense of well-being. When he read the verses, the secretary was so pleased that he gave all that he had received for Nowruz to the poet. ${ }^{28}$

The Nowruz poem is intended to amplify the poet's modest gift in response to his patron's pressure and the competition of his peers. It is so successful in doing so that it ends up leading to the patron's delight, a surfeit of gifts, and a clear victory over the other companions. The poem addresses the problem behind the gift exchange, the poet's poverty and the patron's pressure on him to live up to his gift-giving obligations. The characters in this Persian New Year story refer to the serious business of uncertainty and risk in patronage, while implying a step back from this serious business that validates refined manners as a less stressful alternative.

In the third gift story that foregrounds the writer's difficulties, alBuhturī coveted a male slave who belongs to Muhammad b. Humayd b. ${ }^{\mathrm{c}}$ Abd al-Hamīd (d. 214/829), known as a son of the Abbasid general who helped to defeat the rebel Bābak, and as a refined poet. Al-Buhturī composed a poem in which he requested the male slave as a gift and also complained about his other male slaves. ${ }^{29}$ Other elites who heard the poem were so impressed that they sent slaves as well. The Khālidī brothers cite a long section of the poem, which includes a description of the slave. ${ }^{30}$ Al-Buhturī amplifies his request for his patron's slave with the poem, which in turn leads to a surfeit of gifts that far exceeds the initial request. The refined rhetoric of the poem alludes to the problem that offers a context for the request, al-Buhturî's acquisitiveness. The link between the poem and the surfeit of gifts addresses the problem by getting al-Buhturī what he wants.

The acquisitiveness in this brief gift exchange story takes place in the realm of manners and echoes al-Buhturī's acquisitiveness in the more serious business of political panegyric. In his work as a highly successful panegyrist and avid admirer of slave boys, al-Buhturī (d. 284/897) was sometimes described as excessively acquisitive. In terms of panegyric, he

\footnotetext{
28 Al-Khālidiyyān, Tuhaf, p. 36.

29 Al-Buhturī, Dīwān al-Buḥturī, 5 vols, ed. Ḥasan Kāmil al-Ṣirafî (Cairo, n.d.), 1:39.

30 Al-Khālidiyyān, Tuhaf, pp. 71-3.
} 
became famous for switch his loyalties to sell poetry. He was at the gathering where the caliph al-Mutawakkil was assassinated, but was able to use intercession with the minister Ibn al-Khașīb to connect with alMutawakkil's son al-Muntașir, who was part of the plot and who became the next caliph. Later, when the caliph al-Musta ${ }^{c} \bar{i} n$ purged Ibn al-Khași 1 , he supported him. He praised al-Musta ${ }^{c} \bar{i}$ and then composed invective on him after he was deposed. ${ }^{31}$ In the realm of manners, he is said to have sold his favorite slave boy, Nasìm, and schemed to put him in the possession of the kind of people who supported literature. He would then compose poetry to win him back. ${ }^{32}$ In stories about al-Buhturī, the theme of acquisitiveness links the serious business of politics and the less formal realm of manners.

In each of these three short stories that begin with the writer's difficulties, about Ibrāhīm b. al-Mahdī, the poet on Nowruz, and alBuhturī, rhetoric is more significant than the initial gift that is given or requested, and leads to a surfeit of gifts. The rhetoric, the initial gift, and the surfeit of gifts convey the complications of relationships. Ibrāhīm b. al-Mahdī and Ishāa b. Ibrāhīm al-Mawșilī are rival colleagues, the poet in Iran is poor but under pressure to offer a gift, and al-Buhturī is acquisitive in both formal and informal settings. A gift not given or a gift not accepted, according to Mauss' theory of socially embedded gifts, implies a breakdown of communal bonds. These three brief stories show that socially embedded gifts that are exchanged can convey relationship problems. The overwhelming success of each exchange, in which rhetoric amplifies a relatively modest gift and leads to a surfeit of gifts, helps to illuminate the social tensions that serve as a backdrop for the interaction.

Gifts of aggression and social tension

In brief gift exchange stories like the ones discussed above, the rhetorical focal point of an apt phrase or a verse dominates the text. In contrast, the following pair of longer stories examines the causes and consequences of gift exchange more gradually, while the rhetorical focal points help to reinforce the significance of the interaction. Other stories help to situate the gift exchange as a marginal, yet meaningful, intervention into the

31 Hāshim Mannā̄ ${ }^{\mathrm{c}}$,al-Buhturī: hayātuhu wa-shi ${ }^{c}$ ruhu (Beirut, 2002).

32 Al-Ișfahānī, $A g h \bar{a} n \bar{\imath}, 21: 52$. Rowson compares this version with another less negative one (Everett K. Rowson, "The Traffic in Boys: Slavery and Homoerotic Liaisons in Elite 'Abbāsid Society”, Middle Eastern Literatures 11/2 (2008), pp. 193-204). 
more serious business of political life. In these gift exchange stories, business as usual is turned around, either temporarily or permanently, and the gift exchange, including the gift and the rhetoric that circulates with it, reflects this unexpected turn of events.

Several features define the two stories about social tension in this section, as well as the two stories about political crisis in the following section. First, the pleasure of the material gift appears incongruent with the anxiety surrounding social tension, and throws it into relief. Second, in each story, the rhetorical focal point reverberates in the silence that surrounds it. This silence is as important as the rhetorical focal point itself in conveying the aggression and anxiety through which the gift exchange displays clashes over social tension. Finally, each story includes confrontation that occurs at a distance, either through the use of writing or the sending of messages, which serves as another way to amplify social tension. The conventions of stories narrated by transmitters about historical characters preclude extensive, explicit portrayals of the inner life of characters. ${ }^{33}$ However, these conventions not only make space for implicit portrayals of inner life, they foreground them. The features that define these gift exchange stories - the incongruence between the fine gift and the tense situation; the use of rhetorical focal points and tense silence; and communication at a distance that allows confrontations to unfold in a gradual way-combine to provide implied perspectives on the inner life of characters. The emotional life of historical characters in texts like these takes shape in public gestures. ${ }^{34}$ These three features of the stories are on display in the narrative, so that they are in effect public gestures. It is as if the individual's emotional experience were understood through a communal consensus, in which emotion is encoded in the features of the stories.

The following story features the Abbasid wazīr al-Fayḍ b. Abī Șālih, who was born in Nishapur and is said to have been a slave of the highly skilled writer and secretary Ibn al-Muqaffa ${ }^{c}$, which would have allowed

33 Stefan Leder, "The Literary Use of the Khabar: A Basic Form of Historical Writing" in Averil Cameron and Lawrence I. Conrad, eds., The Byzantine and Early Islamic Near East: Problems in the Literary Source Material (Princeton, 1992).

34 James Montgomery, "Convention as Cognition: On the Cultivation of Emotion" in Marle Hammond and Geert J. van Gelder, eds., Takhyīl: Source Texts and Studies (Warminster, 2007). 
him to gain skills in administrative work. ${ }^{35}$ In this story, Fayd and the secretary Ahmad b. Junayd clash over the conflict between the social hierarchy at work and the value of mutual respect in their community of professionals.

Aḥmad b. Abī Khālid relates that al-Fayḍ b. Abī Șālih and Ahmad b. Junayd and a group of high-ranking secretaries left the residence of al$\mathrm{Ma}^{\mathrm{J}}$ mūn on their way home on a rainy day. Fayḍ went first followed by Ahmad b. Junayd, and Fayḍ's mount splashed rain water on Ahmad's clothes. Ahmad said "Uff!" in disgust and annoyance and said to Fayḍ, "By God, this is a really vile way to travel together. What gave you the right to precede us?" Fayḍ remained silent until he got home, and then summoned his assistant and ordered him to prepare a hundred chests, each containing a shirt, pants, an undergarment, and a tall hat. And he did so. Then he said, take these chests on the backs of a hundred porters to Ahmad b. Junayd's house and say to him: "This is what gave us the right to proceed you, that we have the likes of this to give to you as a gift to you when we ruin your clothes. And if you were to give the likes of this to us when you preceded us and your mount ruined our clothes, we would let you go ahead of us."36

At work, the minister Fayḍ precedes the secretary Aḥmad, but Ahmad seems to think that on the way home, they owe each other the mutual respect of sharing the road. Ahmad thinks that professional hierarchy is bounded by more egalitarian values of good manners and mutual respect, and is outraged when these values are ignored. Fayd's reaction to his outburst shows that he sees professional hierarchy as a total definition of the identity of each man. For Ahmad, the social and bodily discomfort of having his clothes ruined by Fayḍ's mount is a disruption of the values of manners and mutual respect, and his outburst says as much. For Fayḍ, it is Ahmad's objection, not the ruined clothes, that represents a disruption of professional hierarchy. The story offers a view of social order as a contested practice rather than a fixed framework for interaction.

Fayḍ asserts his view in two ways: first in his passive aggressive silence in response to Ahmad, and then in the preparation of the gift and the rhetorical focal point of the aggressive message to accompany it. The surfeit of gifts reinforces Fayd's assertion of his view in response to Ahmad's demand for good manners and mutual respect. The comfort

35 Dominique Sourdel, Le vizirat 'A Abbāside de 749 a 936, 2 vols. (Damascus, 1959), 1:111.

36 Al-Khālidiyyān, Tuḥaf, pp. 117-8. 
associated with the luxurious gift is used in an incongruous way to convey Fayḍ's aggressive point about subordinating Ahmad. The excessive number of outfits makes the gift echo the theme of ceremonial robes at court to assert the giver's superiority, the recipient's subordination, and the value placed on social hierarchy. However, a contrast is implied. The subordinate person would offer a tactfully performed service or well-wrought rhetoric, not have his clothes ruined by a riding animal, as a reason to receive a ceremonial robe. The ruined outfit is a social and bodily sign that displays Ahmad's subordination. In addition, the series of outfits may be a social and bodily sign that Ahmad is ultimately as replaceable as his clothing.

The rhetorical focal point of Ahmad's outburst reverberates in the silence of Fayd The gift and the message are prepared and portrayed but not actually given in the story. The confrontation expressed in Fayd's message takes place at a distance. Like Ahmad's outburst followed by Fayḍ's silence, the message reverberates in Ahmad's implied silence. The parallel of each man's angry words followed by the other's silence implies the conflict between their views of social status.

Ahmad's objection is inscribed within Fayḍ's assertion of social hierarchy, but is also disruptive of it. Fayḍ's message, explaining why the gift means that Fayd is superior to Ahmad, also refers to the hypothetical possibility that Ahmad could ruin Fayḍ's clothes if he could give Fayd such a gift. In this comment, Fayd clarifies that the importance of social hierarchy is ranked positions, not the people who occupy them.

Other depictions of Fayd complement his aggressive deployment of the gift in this story. He was known to be generous and noble as well as arrogant, domineering, and haughty. In one story, Fayḍ went to see the caliph Hārūn al-Rashīd, who extended his hand for Fayḍ to kiss, but instead of bending down to kiss it, he lifted it to his mouth and kissed it. Al-Rashīd said, "If he were not so lowly and stupid, I would kill him." 37

Fayd's generosity could be a weapon of aggression, as it is in the story about the hundred outfits, as well as a benefit to others, as it is in the following story. The Abbasid $\mathrm{Umm} \mathrm{Ja}^{\mathrm{c}}$ far had a secretary who threw a man in prison because he owed money from Umm $\mathrm{Ja}^{\mathrm{c}}$ far's agricultural land. The man in prison appealed to two friends, who set out to meet the secretary. Fayd saw them on the road, asked them what was going on, and offered to help out when he learned about their mission. In one version, the men had the secretary write to ask for their friend's release,

37 Abū ${ }^{\mathrm{c}}$ Abd Allāh Muhammad b. ${ }^{\mathrm{c}}$ Abdūs al-Jahshiyārī, Kitāb al-Wuzară ${ }^{\supset}$ wa-l-Kuttāb, (Cairo, n.d.), p. 123. 
and Umm $\mathrm{Ja}^{\mathrm{c}}$ far responded, "Not without the money." One man got up to go. In the other version, the same thing happens, but the friend said "We have fulfilled our obligation to the man. Umm $\mathrm{Ja}^{\mathrm{c}}$ far will not release him unless the money is paid. Let's go." This version emphasizes the friend's failure to make an effort and Fayd's virtue in the scene that follows in both versions. Fayd said, "It's as if we came here (merely) to confirm that the guy is in prison! By God, we'll pay the money for him." He took the inkstand and wrote out a document for payment. Umm Ja far decided that she was more suited to the good deed and had the document returned to Fayḍ. The story concludes with the observation that Fayd did not even know the man in prison, and he just went to help out his two friends. ${ }^{38}$ The contrast between the gift exchange story and the debt relief story, also a kind of gift exchange, demonstrates that gift exchange did not have an inherent ethical or emotional value, but could be loaded with aggressive or benevolent value according to circumstances. Likewise, the contrast between the two stories demonstrates the complexity of Fayḍ as a character.

The following gift exchange story displays social tension through an argument between a caliph and his wife over the caliph's mawlä, or client. The client of the Abbasid caliph Abū 1- ${ }^{\mathrm{c}}$ Abbās al-Saffāḥ, ${ }^{\mathrm{c}}$ Umāra b. Hamza, and the caliph's wife, Umm Salama bint Ya ${ }^{c} q u \bar{b}$ b. Salama alMakhzūmiyya, clash because of the caliph's effort to use ' Umāra against Umm Salama, who was a former member of the Umayyad dynasty, in an argument about social status. Their argument alludes to tensions between the Abbasids and the Umayyads, and between patron elites and client elites. The story of Fayḍ and Ahmad features Ahmad's failed challenge to social hierarchy, as well as Fayd's hypothetical inversion of hierarchy ("If you could buy us a hundred outfits, you could ruin our clothes"). In contrast, the gift exchange story about the caliph, his wife, and the caliph's client depicts a more successful challenge to social hierarchy and an actual inversion of it.

${ }^{c}$ Alī b. ${ }^{c}$ Abbās the secretary related to us saying: Abū al- ${ }^{c}$ Abbās al-Saffăh knew his client ${ }^{\mathrm{C}}$ Umāra b. Hamza for his arrogance, haughtiness, and dignity. One day Abū al- ${ }^{\mathrm{c}}$ Abbās had an altercation with Umm Salama alMakhzūmiyya, his wife, in which she bragged to him about the superiority

38 Al-Jahshiyārī, Wuzarāa ${ }^{\jmath}$, p. 124; Al-Qāḍī Abū ${ }^{\mathrm{c}}$ Alī al-Muhassin b. ${ }^{\mathrm{c}}$ Alī alTanūkhī, al-Faraj $b a^{c} d$ al-shidda, 5 vols., ed. ' Abbūd al-Shāljī (Beirut, 1978/1398), 2:120-1. The minister Yahyā b. Khālid al-Barmakī, who used to demur when praised for his generosity, would say "you should have seen Fayḍ!"” (Al-Jahshiyārī, Wuzarāa $\bar{a}^{\circ}$ p. 123). 
of her family, and he said to her, "I will bring to you this minute, with no preparation, a client of mine the likes of whom you will not find in your family."

Then he commanded that ${ }^{c}$ Umāra b. Hamza be brought as is, and the messenger went to him; and ' $\mathrm{C}$ māra tried to change his clothes but the messenger would not let him. He brought him to Abū $1-^{c}$ Abbās while Umm Salama was behind the curtain, and ${ }^{\circ}$ Umāra was in clothes scented with musk, having sprinkled his beard with perfume until it laid straight and his hair was concealed. He said, I did not want the commander of the faithful to see me like this. And Abū l- ${ }^{\mathrm{c}} \mathrm{Abbās}$ threw him a container with perfume in it that he had in front of him and ${ }^{\mathrm{C}}$ Umāra said, commander of the faithful, do you see a place for that in my beard?

- Then Umm Salama passed to him a necklace of great value, and the servant gave it to him and ${ }^{~} \mathrm{Uma} r a$ left it in front of him. He thanked Abū l${ }^{\mathrm{c}} \mathrm{Abbās}$ and stood up. Umm Salama said to Abū $1-^{\mathrm{c}} \mathrm{Abbās}$, he forgot it. He said to the servant, catch up with him and tell him that this is a gift from Umm Salama to you, why did you leave it behind. The servant followed him and said, this is for you, why did you leave it? And he said, it's not mine, take it back. When the servant notified him that Umm Salama gave it to him as a gift, he said, if you're telling the truth, then I've given it to you as a gift.

The servant departed with the necklace, and notified Abū 1- ${ }^{\mathrm{c}}$ Abbās of what happened, and Umm Salama said, return my necklace to me. The servant refused to return it, and said, he gave it to me as a gift just as you gave it to him as a gift, and she did not stop until she had bought it from him for 10,000 gold coins. ${ }^{39}$

The location of the story at the head of the Khâlidīs' chapter on people who refused a gift out of pride, complements the broader issue of 'Umāra's contradictory position as a client and the use of gift exchange to articulate social tension.

The story turns on the incongruous combination of al-Saffăh's pride in his client, who is therefore summoned without advance notice to serve as evidence in his argument with his wife, and the degradation that this sudden summons entails for ' Umāra. 'Umāra's haughtiness makes him the perfect weapon for al-Saffāh in his altercation with his wife, while being used in this way is also particularly degrading for ${ }^{\mathrm{c}}$ Umāra due to his pride. His degradation is a social and bodily experience of awkward discomfort, which he sums up when he tells Abū 1- ${ }^{\mathrm{c}} \mathrm{Abb} a \bar{s}$ that he did not want to be seen that way.

The scene in which the caliph tosses some perfume to his distraught

39 Al-Khālidiyyān, Tuhaf, pp. 143-5. 
client serves as a kind of prelude to the Umm Salama's attempt to give ${ }^{c}$ Umāra the necklace. Although 'Umāra appears without advance notice, with some hasty and minimal adjustments, he seems to find the caliph's gift of perfume both unnecessary and insulting, as his indignant retort conveys. The sensory pleasure associated with perfume is incongruent with the rudeness of the summons and the insult felt by ${ }^{\mathrm{c}}$ Umāra at this modest gift. Because it is perceived as rude and insulting, the act of Abu al- ${ }^{\mathrm{c}}$ Abbās tossing perfume to ${ }^{\mathrm{C}}$ Umāra is a distortion of gift exchange.

'Umāra's indirect confrontation with Umm Salama may be just the

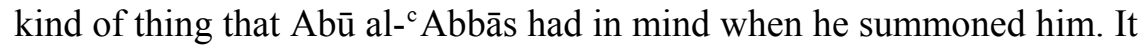
is resistance to Umm Salama's assertion of superiority over ' Umāra in her attempt to give him the necklace. At the same time, the indirect confrontation contributes to Abu $1-^{c}$ Abbās' assertion of his own superiority over Umm Salama. Like 'Umāra's refusal of the perfume, his refusal of the necklace relates to his social and bodily disgrace due to being summoned without notice, and his insistence that he has no need for any improvements. The gracious voluntariness that is identified with gift exchange throws the coercive quality of this attempted gift exchange into relief. When he ignores the necklace and rises to leave, ${ }^{c}$ Umāra acts out his subordination with his polite thanks for the degrading encounter, while also doing his own thing. His polite thanks for the rude treatment reverberate in the silence with which he responds to the gift of the necklace. Similarly, the distortion of gracious gift exchange, in which Umm Salama says that he has forgotten it, reverberates in the silence with which ${ }^{\mathrm{c}}$ Umāra responded to the gift of the necklace.

While servants are merely agents who deliver Umm Salama's aggressive gift, and who redeliver the gift on the orders of her husband, ${ }^{\mathrm{c}}$ Umāra disrupts the social hierarchy when he gives the gift to a servant without ever having touched it himself. In this scene, ${ }^{c}$ Umāra moves beyond the subdued resistance of his comment that he did not want to be seen that way, the indignant resistance in his refusal of the perfume, and his passive aggressive resistance in ignoring the gift. His confrontation with Umm Salama takes place at a distance, by way of the servant. Umm Salama fails to subordinate ${ }^{\mathrm{C}}$ Umāra and is herself subordinated by him, if only in an indirect and roundabout way, when she finds herself in the ridiculous situation of buying back her own gift from the servant. Abū 1'Abbās's client is not only better than her family, he's better than her. The aggression of the gift is matched by the aggression of the refusal, especially 'Umāra's act of giving the gift to the servant instead of simply walking away from it. It's not clear whether ' Umāra's action has served Abū 1- ${ }^{\mathrm{c}}$ Abbās's original purpose, when he offered ${ }^{\mathrm{c}}$ Umāra as an example 
to his wife as a token of his resentment, or has gone overboard.

The tension between the Abbasids and the Umayyads, who had been deposed or had fled to Spain, is the context for this story. During the

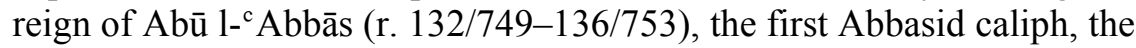
dynasty worked with a variety of factions but excluded the Umayyads, the former ruling dynasty. ${ }^{40}{ }^{\mathrm{c}}$ Umāra $b$. Hamza, a secretary and a client of Abū 1-'Abbās al-Saffāh and two other caliphs, was known for his eloquence and supervised agricultural land that had belonged to the Umayyad dynasty, so that the tension over the social status of clients intersects with the tension between the Abbasids and the Umayyads in this story. ${ }^{41}$ 'Umāra enjoyed considerable power but his status was limited by his position as a client. Though she married into the Abbasid dynasty, Umm Salama remained a figure of the transition between the Umayyads and the Abbasids.

Umm Salama's role as a transitional figure between the Umayyads and the Abbasids appears in stories about her marriage to Abū 1- ${ }^{\mathrm{c}} \mathrm{Abba} s$. Abu $1-^{\mathrm{c}}$ Abbās was the first caliph of the Abbasid Empire and Umm Salama had been married and widowed twice, to two members of the Umayyad royal family. Brides are typically given in marriage. In one story, Umm Salama gave Abū 1- ${ }^{\mathrm{c}}$ Abbās a gift of money and in effect offered herself as a gift instead of being given in marriage. Umm Salama was sitting one day when Abū $1-^{c} A b b a ̄ s$, who was very handsome, passed by. She asked about him and found out who he was, and sent a female client of hers to propose to him. Umm Salama said, "Tell him, here's seven hundred gold coins that I'm sending to you." The client approached him with a great deal of money, jewels, and many followers and made the proposal. Abū 1-'Abbās responded, "I'm broke," accepted the money, and thanked Umm Salama's client graciously. He arranged the marriage with Umm Salama's brother and used the money that she gave him for his own marriage-related financial obligations. On the wedding night, she lied down on her bridal bed, every part of her body covered with jewels. He could not consummate the marriage. She called one of her slave girls, changed into a dyed garment, and made a bed for him on the floor. He still could not consummate the marriage. She said, "Don't worry about it, the same thing has happened to other men." She

40 Hugh Kennedy, The Prophet and the Age of the Caliphates, (London, 1986), pp. 128-30.

41 Yāqūt, $M u^{c}$ jam al-Udabāo, 7 vols., ed. Iḥsān 'Abbās (Beirut, 1993), 5:2054-6. 
did not give up until they consummated the marriage, and he appreciated her and swore that he would never go near another woman, free or slave. She had two children by him and dominated him, so that he would not do anything without consulting her. ${ }^{42}$ The marriage story is followed by a second marriage-related story that underscores the power of Umm Salama in the match, in which she prevented her husband from pursuing other women. ${ }^{43}$ While ${ }^{\mathrm{C}}$ Umāra is the go-between in the conflict between Abū $1-^{c}$ Abbās and Umm Salama in the gift exchange story about

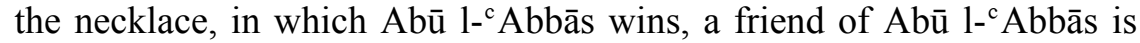
the go-between in their marriage conflict in the story about preventing other relationships with women, in which Umm Salama wins. The friend was the one who suggested to Abū $1{ }^{c} A b b a \bar{s}$ to enjoy other women, but he changed his tune quickly after Umm Salama sent some men to his house to threaten him, and he enjoyed her generous reward as a result of

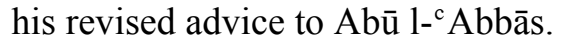

Umm Salama serves as an important transitional figure, and another "gift exchange" story about her appears in the second extant book on gift exchange from the fifth/eleventh century. The deposed Umayyads turned over their jewels to Abū 1- ${ }^{\mathrm{c}} \mathrm{Abbās}$, but Umm Salama said, "Why don't I see "Abda's vest?" The jewel-studded vest was missing. One version of the story, which is defined by two writers as a gift exchange story, is enhanced by the fact that ${ }^{\mathrm{c}} \mathrm{Abda}$ is marked for catastrophe. Her husband, the Umayyad caliph Hishām, noticed a birthmark on her neck when she had taken off her jewelry. He burst into tears and when she asked him what was wrong, he explained "They say that the daughter and wife of a caliph with a birthmark on her neck is doomed." She asked him why he told her such a thing when nothing could be done. Umm Salama insisted that ${ }^{\mathrm{c}} \mathrm{Abda}$ be brought from Syria to Iraq to deliver the missing vest in person, but ${ }^{\mathrm{c}} \mathrm{Abd}$ Allāh $\mathrm{b}$. ${ }^{\mathrm{c}} \mathrm{Ali}$, who was in charge of her, could not stand the idea of her being taken. He had her killed by his own men on the road, in a dramatic scene in which she asked to be allowed to cover herself in her robe (and, in the later version, pray), and covered her entire body except for her neck. ${ }^{\mathrm{c}}$ Abd Allāh b. ${ }^{\mathrm{c}}$ Ali said that she was killed by

42 Al-Mas ${ }^{\mathrm{c}} \overline{\mathrm{ud}} \mathrm{i}$, Murūj al-dhahab wa-macādin al-jawhar, 4 vols, ed. Mufĩd Muhammad Qumayḥa (Beirut, n.d.), 3:315-6.

43 Ibid., 3:316-20. The story is really a combination of stories (Jaakko HämeenAnttila, "Short Stories in Classical Arabic Literature: The Case of Khālid and Umm Salama" in Lale Behzadi and Vahid Behmardi, The Weaving of Words: Approaches to Classical Arabic Prose (Beirut, 2009), pp. 35-54). 
the Bedouin, and the vest remained with him until it was taken by another caliph. ${ }^{44} \mathrm{Umm}$ Salama mediates the transition between the Umayyads and the Abbasids by way of jewels when Umm Salama gives herself to Abū 1- ${ }^{c} A b b a \bar{s}$ covered in jewels, albeit consummating the marriage only after changing into less dazzling attire, and when she tosses her necklace to ${ }^{~}$ Umāra in her argument over the relative merits of her family and her husband's clients. Likewise, she plays a crucial role in the circulation of the legendary jeweled vest as a figure of the transfer of power from the Umayyads to the Abbasids.

Depictions of ${ }^{c}$ Umāra complement his role in the gift exchange story and clarify the contradictions of client status. ${ }^{c}$ Umāra was said to combine the positive quality of nobility and the negative quality of haughtiness. ${ }^{45}$ As in the depiction of Fayd, this characterization emphasizes the complexity of personality in the dynamics of social hierarchy. While the depiction of Fayd in the story of the hundred outfits focused on his superior position as minister, the depiction of ${ }^{\mathrm{c}}$ Umāra in the necklace story focuses on his contradictory position as a powerful yet subordinate client. 'Umāra, as a man with a chip on his shoulder, can be compared to pompous and proud characters such as Ibn al-Muqaffa ${ }^{\mathrm{c}}$, who trained Fayḍ b. Abī Șālih, and members of the Barmakid family. ${ }^{46}$ They are perceived as pompous and proud in the context of the assumption that they are actually subordinate no matter how high they may rise in the elite. For ${ }^{\mathrm{C}}$ Umāra, refusing the necklace is a way to claim status that is denied to him because of his position as a client.

Other stories about ${ }^{c}$ Umāra offer insights into his contradictory status in the necklace story. Some stories emphasize his noble character in the context of administrative work, such as one in which the minister Yahyā b. Khālid al-Barmaki urgently needed help in a financial crisis. When Abū Ja ${ }^{c}$ far said:

"Who do you think can help?" Yahyā said, "I don't know," and Abū Ja far responded, "Yes you do, 'Umāra b. Ḥamza, go tell him what's going on." Yahyā said, "I went to his residence on the other side of the river and explained the problem, and ${ }^{\mathrm{c}}$ Umāra told me to meet him at the bridge in the morning and said nothing else. I returned dejected, but Abū $1-^{\mathrm{c}} \mathrm{Abbās} \mathrm{said,}$ 'Don't worry, that's just the way he is.' The next day, I went to the bridge

44 Al-Dhakhā̄ir wa-l-Tuhaf, pp. 93-5; Al-Ghuzūlī, Mațālic al-Budūr fĩ Manāzil al-Surūr (Port Said, 2000/1419), p. 455.

45 Al-Jahshiyārī, Wuzarā̄ , p. 60; Yāqūt, Mucjam al-Udabāo , 5:2054.

46 Sourdel, Vizirat, p. 178. 
but the Tigris had flooded and broken the bridge. A small boat approached, appearing and disappearing in the waves as people cried, 'Someone's drowning! Help them!' until it approached the shore and it was 'Umāra and a sailor. He had left his slave boys and mount behind. When I saw him, he was noble in my eyes and I was all choked up. I went down and greeted him, and said, 'I can't tell you how much I appreciate your coming on a day like this,' and he said, 'Did you think I would make an appointment with you and stand you up, my friend"?"47

This story emphasizes 'Umāra's nobility by juxtaposing Yahyā's uncertainty with the reassurances of the two members of the royal family, and by turning an administrative appointment on a stormy day into a heroic act.

Some stories about ${ }^{c}$ Umāra offer a comic perspective on his sometimes uncomfortable position as a client. ${ }^{c}$ Umāra went to the caliph al-Mahdī and the caliph expressed his respect for him. When he rose to leave, a man (or men) from Medina from Quraysh said, "Who is this guy to whom you expressed so much respect?" The caliph said, "This is my client "Umāra b. Hamza." "Umāra heard what he said and returned to him and said, "O caliph, you made me sound like one of your bakers or servants, if only you had said ' Umāra b. Hamza b. Maymūn the client of ${ }^{\mathrm{c}} \mathrm{Abd}$ Allāh b. ${ }^{\mathrm{c}} \mathrm{Abbās}$ so that people would know my place!"48 As a client, "Umāra was powerful, yet vulnerable. When the Abbasid Mūsā al-Hādī heard of the beauty of ' Umāra's daughter, he got in touch with her and eventually arranged to meet her for a secret date in a room that had been prepared for him. ${ }^{\mathrm{c}}$ Umāra walked in on the meeting and said to al-Hādī, "Greetings, prince, what are you doing here? We've made you the heir to the throne, not the stallion for our women." "Umāra laid him down on the floor and beat him lightly before sending him home, and al-Hādī always resented him for it. ${ }^{49}$ As in the story with Umm Salama, 'Umāra's status as a client made him vulnerable to insults, while his ample self-confidence enabled him to respond in an assertive or even aggressive way. The circulation of gifts in the stories about Fayḍ b. Abī Șālih and Ahmad b. Junayd, and about Abū 1- ${ }^{\mathrm{C}}$ Abbās, Umm Salama, and ${ }^{\mathrm{c}}$ Umāra, show that gift exchange can articulate social tensions as well as communal bonds.

\footnotetext{
47 Al-Jahshiyārī, Wuzarā̄ , p. 61-2.

48 Ibid., p. 107; Yāqūt, Mucjam al-Udabāa , 5:2062.

49 Al-Jahshiyārī, Wuzarā̄o $^{\text {, p. }} 107$.
} 


\section{Gifts and political crisis}

The tensions surrounding social status and political hierarchy in the stories of Fayḍ and Aḥmad, and of Abū 1- ${ }^{\mathrm{c}} \mathrm{Abbās}$, Umm Salama, and ${ }^{\mathrm{c}}$ Umāra, sometimes gave way to crisis. The Khālidī brothers interpret the caliph Hārūn al-Rashīd's purge of the powerful Barmakid administrative family in terms of a "gift exchange" story. Similarly, the anonymous Fatimid author of the eleventh-century Book of Treasures and Rarities elaborates on the assassination of the caliph al-Mutawakkil by his Turkish generals and his own son in a "gift exchange" story. The question of how to share material luxuries serves as an occasion to reflect on the significance of political crises. As in the stories about gifts and social tension, three features define these stories about gifts and political crisis. First, the pleasure of the material gift appears incongruent with the anxiety surrounding the crisis and throws it into relief. Second, in each story, the rhetorical focal point stands out in the silence that surrounds it. This silence is as important as the rhetorical focal point itself in conveying the aggression and anxiety through which the gift exchange displays the crisis. Finally, each story includes confrontation that occurs at a distance, either through the use of writing or the sending of messages, which serves as another way to amplify the crisis. As in the stories about social tension, these features combine in the stories about gift exchange and political crisis to provide implied perspectives on inner life.

Like many writers before and after them, the Khālidī brothers bring the story of the fall of the Barmakids, the most powerful administrative family in the Abbasid Empire, into their treatment of their topic, gift exchange. They were known for centralizing the administration, and as a result, their consolidation of administrative power threatened other elites, including the military and eventually the Abbasids themselves. The Abbasid Hārūn al-Rashīd became caliph in 170/786 and Yahyāa, and later his two sons $\mathrm{Ja}^{\mathrm{c}}$ far and al-Faḍl, became important figures in the Abbasid government. In 180 their power began to decline, partly because Hārūn no longer wanted to be dominated by any one faction, and their famous fall occurred in 187/802.50 In spite of the political causes of their demise, the legends that circulate about the family's downfall after seventeen years of running the Abbasid administration seem to be about surprise and shock at the way close relationships can fall apart. ${ }^{51}$

The immediate context of the story in the Khālidīis' book is a series of

50 Kennedy, Prophet, pp. 140-3.

51 Barthold, W., Sourdel, D. “al-Barāmika or Āl Barmak", EI², 1033-6. 
gift notices accompanied by poems that define the way they analyze their Barmakid story. It is significant that this series of gift notices with poems, which culminates with the Barmakid story, is right at the beginning of the book, after the brief introduction, in the first chapter (Those Who Gave a Gift Accompanied by Poetry). Given this initial focus on gift exchange that is extremely problematic, it is not surprising that gift exchange as an expression of relationship problems, ranging from transient altercations to deadly confrontations, features prominently in the rest of the book.

The prelude to the Barmakid story consists of four notices about gifts to ruling elites - a sword for the general Yazīd b. Mazyad, who succeeded his uncle $\mathrm{Ma}^{\mathrm{c}} \mathrm{n}$ b. Z $\overline{\mathrm{a}}^{\curvearrowright} \mathrm{ida}$ as a tribal leader of Shaybān; a falcon for Muhammad b. ${ }^{c}$ Abd Allāh b. Țāhir; a horse for the caliph alMutawakkil, who was assassinated; and a sword for the general (and poet and musician) Abū Dulaf. The theme of hunting and war in the series of gifts contributes to the literary interest in gift exchange as an expression of coercion and conflict in the Barmakid story. Most importantly, each poem includes the motif that it is haräm for the servant to keep what is suitable for the master (instead of giving it to him). Fayd b. Abī Sālih, in the story discussed above, pointed out that if Ahmad b. Junayd could buy a hundred outfits for Fayd, then he could get mud all over Fayḍ's clothes. This view of status that follows from wealth contrasts with the series of gift notices that lead up to the Barmakid story, where wealth follows status. The servant cannot rise in status relative to the master due to his wealth. Instead, he must turn that wealth over to the master in recognition of the latter's status and to help maintain it. To keep what is suitable for the master instead of giving it as a gift would be tantamount to rebellion, and this is how the Barmakid demise is imagined.

In their transition from the series of gift notices with poetry to the Barmakid story, the Khālidī brothers seem to imply that they are adding on their story of the Barmakid demise as an afterthought. It is hard to take this implication at face value, given the enormous influence of the event in Arabic literary culture. This implication seems to be about reinforcing the fact that they are embedding the famous story in the series of notices that revolve around poems about gift exchange. The story is transmitted by a descendant of the Barmakid ministers who was known as a musician, literary type, and companion to an Abbasid caliph. The descendant as transmitter lends the story immediacy, and the contrast between the administrative power of the ministers and the entertainment position of the descendant calls attention to the fact that 
the family was marginalized but not destroyed. The "gift exchange" story of the Barmakids is not really about gift exchange, and the series of notices with poetry that leads up to it is not really story. However, the Khālidī brothers weave the story and the poetry notices together to forge a gift exchange story, and to offer a perspective on the ubiquitous topic of the fall of the Barmakids.

We do not know anything with this exact meaning- [that it is forbidden for the servant to keep what is suitable for the master instead of giving it to him as a gift] - aside from what we've mentioned, other than a verse in some verses that we deem sound in an anecdote told to us by Jahzā alBarmakī. Jahuzā l-Barmakī related to us, saying: "The most certain of causes for the killing of my uncle $\mathrm{Ja}^{\mathrm{c}}$ far $\mathrm{b}$. Yahyā l-Barmakī and the cease of benefit for his family is some verses that a poet composed when $\mathrm{Ja}^{c}$ far built his house at the Shāmisiyya Gate, and threw in the pile of scrap paper, and that ended up in the hands of al-Rashīd when he had sat down to preside over court. When he read it, his face changed, and he looked at it again, over and over, then stamped it and gave it to one of his servants and ordered him to keep it, and he would call for it every day and look at it and stamp it again and give it to the servant until he deposed the Barmakids, and then he showed what was in it, and it was:

"Say to the one who is trustworthy for God among His creation, who is given the power to loose and bind,

This Ibn Yahya $\mathrm{Ja}^{c}$ far has become like you with no boundary between (the two of) you;

Your command depends on his, and his does not depend on anything.

And we fear that he will inherit your kingdom when you disappear into the grave;

For he has built the residence that has no semblance or peer on earth

The likes of which the Persians did not build, nor the Greeks or the Indians;

And your grandfather al-Manșūr, if he had visited it, would not have called it - his own castle - 'paradise'.

Pearls and rubies are its pebbles, and its dust is ambergris

He has equaled you in property, for his doors are crowded with visitors

And the servant does not vie with his lords unless the servant is insolent'."

The final verse of these verses is an inversion of what al-Harīin said [with his gift of a horse to the caliph al-Mutawakkil in the series of verses that lead up to the Barmakid story], "Ownership of what is appropriate for the commander is forbidden to the servant". ${ }^{52}$

52 Al-Khālidiyyān, Tuhaf, pp. 13-8. 
In this gift exchange story, the Khâlidī brothers are interested in the counterpoint between the coercive, yet orderly, social hierarchy implied by the four gift notices with poetry, and the disruption of social hierarchy in the story about the Barmakids. The gifts of swords, a falcon, and a horse are about beauty, status, and power. As a counterpoint to these gift, $\mathrm{Ja}^{\mathrm{c}}$ far's palace is described as a wretched excess of beauty, status, and power. It is only through this comparison that $\mathrm{Ja}^{\mathrm{c}}$ far's palace can be understood as a failure to give a gift to the caliph, like the initial failure of the impoverished poet to give a Nowruz gift to his patron in the brief story discussed above. The beauty and luxury of the palace offer a stark contrast to the fate of $\mathrm{Ja}^{\mathrm{c}}$ far and his family. The Khālidīs generate insights into historical characters and events through their topic of gift exchange.

$\mathrm{Ja}^{\mathrm{c}}$ far was known for his eloquence, but is verbally represented only indirectly, by the anonymous poet's boast about the palace. The poem that al-Rashīd reads but that is withheld from the audience leads to his silent neurosis. Authority figures in medieval Arabic literary culture would write eloquent and morally relevant responses upon letters that they received, in the genre known as $\operatorname{tawqi}^{c} \bar{a} t .^{53}$ Hārūn's repeated review of the poem resembles the practice of writing $t a w q \bar{l}^{c} \bar{a} t$, but instead of writing an authoritative, eloquent, and morally relevant response, he simply stamps the poem and continues to mull over the problem until he has $\mathrm{Ja}^{\mathrm{c}}$ far killed.

Hārūn's obsessive re-reading and stamping of the offending poem in this story resembles the repeated retelling of the Barmakid story in Arabic literature. While the experience of trauma leads to efforts to achieve mastery over an event through repetition, the possibility of mastery is undermined by the compulsive nature of the repetitioninstead of gaining control of the traumatic event, the person is controlled by it through compulsion - and the fragmentation of the experience that occurs in the process of repetition. ${ }^{54}$ Hārūn's prolonged silence about the poem serves as a kind of echo chamber for the undisclosed contents of the scrap paper. This echo chamber amplifies the eventual revelation of the offending poem as a rhetorical focal point.

The Khālidīs' final comment is a kind of zoom lens. It magnifies the

53 Hāshim Mannā ${ }^{\mathrm{c}}$, Al-Nathr fì l- ${ }^{c}$ așr al- ${ }^{c} a b b \bar{a} s \bar{\imath}$ (Beirut, 1999), pp. 212-36; Beatrice Gruendler, "Tawqīc (Apostille)" in Behzadi and Behmardi, eds., Weavers of Words, pp. 101-30.

54 Kaja Silverman, Male Subjectivity at the Margins (New York, 1992), p. 57. 
inversion of social hierarchy by way of the inversion of al-Harīì̄'s motif in the verse about Ja ${ }^{c}$ far's palace. The fact that al-Harīirīs motif of social hierarchy and gift exchange is directed toward the caliph al-Mutawakkil, who was assassinated by his Turkish generals with the help of his own son, compares the rebellious assassination to $\mathrm{Ja}^{\mathrm{c}}$ far's failure to share his wealth with his patron. The comparison is also ironic, since the rebel generals were perpetrators of violence, while $\mathrm{Ja}^{\mathrm{c}}$ far was a victim.

The Khālidī brothers turn the Barmakid problem into a gift that should have been given but was not, and a poem that should have been a gift exchange poem but was instead a boast about a gift that was not given. The gift that was not given might have been bearable, but the boast about it is too much for Hārūn al-Rashīd to take. $\mathrm{Ja}^{\mathrm{c}}$ far ends up resembling a miser who alienates himself by not participating in exchange, with the important difference that miser stories are comic and his story is tragic.

Like any new media technology, the expanding use of writing offered new ways to experience secrecy, disclosure, alienation, and intimacy, as well as anxiety, obsession, and compulsion. Writing is a motif of anxiety in the depiction of Hārūn al-Rashīd, as he repeatedly reviews the offending poem in the gift exchange story about the palace. Writing also offered new opportunities for comparison to highlight the significance of political crises. The Khālidī brothers could draw on the expanding range of bookstores as well as the resources that they enjoyed as librarians in the court of Sayf al-Dawla. ${ }^{55}$

Modern research often views implications of privacy and individualism in medieval Arabic literary culture in a positive way, perhaps because these implications make medieval characters and writers seem more like the way modern people value themselves. In the case of Hārūn, privacy is a condition of misery and anxiety. In the case of $\mathrm{Ja}^{\mathrm{c}}$ far, individualism is defined by the Khālidīs as a failure to be socially engaged, and a failure to cope with social hierarchy so as to take advantage of its privileges and protection. For Hārūn, privacy is a private Hell from which he can never really escape, and for $\mathrm{Ja}^{\mathrm{c}}$ far, individualism is a tragic flaw. In many cases in medieval Arabic literature, word tames

55 "Introduction" in Kushājim, Maḥmūd b. al-Husayn, Dīwān kushājim ed. al-Nabawī c Abd al-Wāhid Shaclān (Cairo, 1997/1417); Shawkat M. Toorawa, "Ibn Abī Ṭāhir Ṭayfūr versus al-Jāḥiz, or: Defining the Adīb" in James E. Montgomery, ed., 'Abbasid Studies: Occasional Papers of the School of 'Abbasid Studies (Leuven, 2004), pp. 247-62; "Introduction" in A1Khālidiyyān, Tuḥaf. 
power. ${ }^{56}$ In this case, the anti-gift exchange poem incites the caliph to violence.

The Khālidī brothers' gift exchange story about Hārūn and $\mathrm{Ja}^{c}$ far complements other stories about their relationship and the crisis. Yahyā b. Khālid al-Barmakī was in charge of the caliph Hārūn al-Rashīd's education, and Yahyā and Hārūn's mother were responsible for paving his way to the caliphate. Each of Yahyā's sons Faḍl and $\mathrm{Ja}^{\mathrm{c}}$ far was in charge of the education of one of Hārūn al-Rashīd's heirs. Faḍl was nursed with Hārūn al-Rashīd and Ja ${ }^{c}$ far was Hārūn's closest companion. Faḍl was known for his great generosity and $\mathrm{Ja}^{\mathrm{c}}$ far for his eloquence. ${ }^{57}$ The whole family did well, but the caliph was particularly interested in $\mathrm{Ja}^{\mathrm{c}}$ far $^{58}$ The danger of this close relationship with the ruler did not go unnoticed. Yahyā would censure $\mathrm{Ja}^{\mathrm{c}}$ far for being so involved with alRashīd and warn about the consequences, and he explained his view to al-Rashīd as well. ${ }^{59}$ The gift exchange story, with its narrow focus on the caliph's anxiety about the relationship, evokes the tense intimacy between the caliph and his companion.

Stories about the rivalry that smolders between $\mathrm{Ja}^{c}$ far and Hārūn complement the gift exchange story, especially one story about the palace that is described in the verses. His father could persuade $\mathrm{Ja}^{c}$ far to give up his reckless pursuit of pleasure, so he told him to build a palace on the other side of the river out of sight of those who might disapprove of his pleasure-seeking. When it was done $\mathrm{Ja}^{c}$ far toured it with some friends, and they offered clever descriptions of it in prose or verse, except for one friend who remained silent. $\mathrm{Ja}^{c}$ far said, "What's the matter? Why don't you join in?" The friend said, "The others have said enough for me." Ja ${ }^{c}$ far could tell he was hiding something and pressured him. The friend told him, "To tell you the truth, I'm worried. What would you think if you went to a friend's palace and it was nicer than yours?" Jac far said, "Enough, I see what you mean." The friend advised him to tell the caliph that he built the palace for the caliph's son al$\mathrm{Ma}^{\mathrm{D}}$ mūn, Ja ${ }^{\mathrm{c}}$ far's student. As predicted, the caliph was upset when he

\footnotetext{
56 Hamori, "Going Down in Style".

57 Barthold, W., Sourdel, D. “al-Barāmika or Āl Barmak”, EI², 1033-6.

58 Al-Rashīd would say to Yaḥyā, you are for al-Faḍl and I am for $\mathrm{Ja}^{\mathrm{c}}$ far (AlJahshiyārī, Wuzarā $\bar{\jmath}^{\jmath}$ p. 145). Al-Rashīd is said to have put $\mathrm{Ja}^{\mathrm{c}}$ far in charge of the west and al-Faḍl in charge of the east, and al-Faḍl went to look after his regions while $\mathrm{Ja}^{\mathrm{c}}$ far stayed with Rashīd.
}

59 Al-Jahshiyārī, Wuzarā $^{\supset}$, pp. 177-8. 
learned of the palace. $\mathrm{Ja}^{\mathrm{c}}$ far told him that it was for al- $\mathrm{Ma}^{\mathrm{D}} \mathrm{mu}$, and that there were some expenses left for the furnishings that he would take from the treasury. The caliph's mood improved, as he boasted that all remaining expenses would of course come from his own funds. ${ }^{60}$ $\mathrm{Ja}^{\mathrm{c}}$ far's friend Ibrāhīm b. al-Mahdī also situates the palace in the context of gift exchange. He said, "Your adversary will take a certain angle, saying to him, 'If he spent twenty thousand on his house, where are his funds for expenses? Where are his gifts? What about the misfortunes that befall him? What do you think is behind that?' And those are words that go straight to the heart..." ${ }^{61} \mathrm{Ja}^{\mathrm{c}}$ far echoed the palace problem himself, saying, "Our house has no flaw except that its owner won't last long," referring to himself". ${ }^{62}$ The Khālidīs' gift exchange story complements these stories of the gift exchange that should have taken place but did not.

The Khālidī brothers appear to suggest that had $\mathrm{Ja}^{\mathrm{c}}$ far followed the formula in the poetry notices, then it would have been haram for the servant to have kept that which is appropriate for the master. When $\mathrm{Ja}^{\mathrm{c}}$ far follows the formula, it works. Al-Rashīd had $\mathrm{Ja}^{\mathrm{c}}$ far race a horse and it beat al-Rashīd's own horse, so that al-Rashīd became angry. Another official at the race stepped in to try to appease the caliph with a story, and told al-Rashīd a story of a similar situation that occurred between the caliph Abū 1-'Abbās al-Saffāh and $\mathrm{Ja}^{\mathrm{c}}$ far's grandfather Khālid, in which Khālid's horse beat the caliph's horse and Khālid told the caliph to go and collect his prize. The caliph agreed that the prize was his, for Khālid was his protégé, so everything that belonged to Khālid was really his. Al-Rashīd's mood improved. ${ }^{63}$

The gift exchange that does not take place represents an inversion of social hierarchy that is ominous, but the same theme also appears in a comic context when $\mathrm{Ja}^{\mathrm{c}}$ far played caliph for a day. He went out of town with his friend Ibrāhīm b. al-Mahdī for a cupping treatment and a party, and gave orders to allow a certain ${ }^{\mathrm{c}} \mathrm{Abd}$ al-Malik into the gathering because he had business with him. The doorman accidentally let in a different ${ }^{\mathrm{c}}$ Abd al-Malik, ${ }^{\mathrm{c}}$ Abd al-Malik b. Șālih al-Hāshimī, who had a reputation for being too uptight to enjoy such a gathering, but whose

\footnotetext{
60 Yāqūt, Muc jam al-Buldān, 7 vols. (Beirut, 1995), 2:3-4.

61 Al-Ṭabarī, Tārīkh al-Umam wa-l-mulūk, 6 vols. (Beirut, 2001/1422),

62 Ibid. 4:659.

63 Al-Jahshiyārī, Wuzarā̄o $^{\text {, p. }} 161$.
} 4:659. 
high social status made it inappropriate to ask him to leave. The uninvited guest managed to participate in the party in an awkward yet adequate way, and $\mathrm{Ja}^{\mathrm{c}}$ far said:

"You've been such a good sport, what can I do for you?" "Abd al-Malik said, "The caliph is angry at me, make him content." Jac far responded,

"The caliph is content with you." "Abd al-Malik said, "I owe 4,000 in gold coins." Ja ${ }^{c}$ far responded, "It's ready to go, from the caliph's money, which is better than my own." "Abd al-Malik said, "I want my son Ibrāhīm to marry into the caliph's family." Jac far responded, "The caliph hereby marries him to his cherished daughter ${ }^{\mathrm{c}} \overline{\mathrm{A}}^{\mathrm{j}}$ isha." "Abd al-Malik said, "I want to see governor's banners flying over his head." Ja far responded, "The caliph has put him in charge of Egypt."

Ibrāhīm b. al-Mahdī expressed amazement at Ja ${ }^{c}$ far's presumptuousness, but $\mathrm{Ja}^{\mathrm{c}}$ far went to al-Rashīd the next day and he loved it, and executed all of Ja ${ }^{c}$ far's commands on his behalf. ${ }^{64}$ The juxtaposition in the sources of the tragic and comic versions of the theme of the inversion of social hierarchy is like a metanarrative about inversion.

The surprise and shock associated with the Barmakid demise are about the way relationships can fall apart on the inside while appearing to function on the outside. This theme is particularly important in the context of medieval Muslim social and professional life, which revolved around individual, informal, and shifting alliances more than formal institutions such as aristocracy, caste, guilds, or civil service systems. ${ }^{65}$ The question of distinguishing reality from appearances was a crucial aspect of refined manners, in the use of close observation and elegant rhetoric in love, friendship, and pleasure pastimes. Likewise, refined manners were a crucial aspect of professional training. ${ }^{66}$

The exchange of women between men in marriage resembles gift exchange, and like gift exchange, it can generate conflict instead of bonds between men. In one story, Hārūn had $\mathrm{Ja}^{c}$ far marry Hārūn's sister ${ }^{\mathrm{c}}$ Abbāsa as a matter of form so that they could all spend time together, stipulating that they would not interact except as party companions in al-

64 Ibn ${ }^{\mathrm{c}}$ Abd Rabbih, Al- ${ }^{c}$ Iqd al-farīd, 7 vols., ed. Muhammad al-Tūnjī (Beirut, 2001), 5:66-7.

65 Roy P. Mottahedeh, Loyalty and Leadership in an Early Islamic Society (Princeton, 1980), pp. 4-6.

66 Norbert Elias, The Court Society, tr. Edmund Jephcott (Oxford, 1983), pp. 101-11; Gadi Algazi and Rina Drory, "L'Amour à la cour des abbassides: Un code de competence sociale", Annales 6 (2000), pp. 1255-82. 
Rashīd's presence, so would not have sex. ${ }^{67}$ This peculiar marriage reinforces the problem of intimacy, since the marriage makes $\mathrm{Ja}^{\mathrm{c}}$ far closer to the caliph, but the stipulation keeps him distant. Unlike a material gift, a human one can change the terms of gift exchange. ${ }^{\mathrm{c}}$ Abbāsa fell for $\mathrm{Ja}^{\mathrm{c}}$ far, and after ingratiating herself with $\mathrm{Ja}^{\mathrm{c}}$ far's mother, as if in a normal marriage, she was able to disguise herself and trick $\mathrm{Ja}^{\mathrm{c}}$ far into having sex with her, and a child was born. This theme of physical misrecognition implies the psychological misrecognition that complicates relationships. The legitimate yet illegitimate child was whisked off to Mecca (a location that offers an ethical counterpoint to the problem of failing relationships), but Hārūn found out about the child from his mother and planned to kill $\mathrm{Ja}^{\mathrm{c}}$ far. In both the palace stories and the marriage story, the breakdown of the relationship is imagined as exchange that has gone awry because one friend withholds what he ought to give to the other. The external action in the marriage story reflects the inner turmoil that Hārūn displays in the gift exchange story.

The caliph's ambivalence about $\mathrm{Ja}^{\mathrm{c}}$ far and his death appears in one version of al-Rashīd's reaction. He could not stand to look at the executioner and ordered him killed. ${ }^{68}$ The caliph's traumatic inability to stop looking at the offending poem in the gift exchange story complements his traumatic inability to lay eyes on the executioner. The more or less real climate of disquiet and various advance signs of the disgrace did not prevent the downfall from being viewed as brutal and mysterious. ${ }^{69}$ Even political problems do not seem to explain the unusual brutality of the treatment of $\mathrm{Ja}^{\mathrm{c}}$ far, whose remains were left exposed in Baghdad for a year. ${ }^{70}$ The Khālidī brothers' gift exchange story explores a crisis of intimacy, reality and appearances in relationships, differences of social status and the inversion of social hierarchy.

While the palace and marriage stories focus on the failure gift exchange to secure relationships across boundaries of status, the Khālidī brothers also include a gift exchange story about $\mathrm{Ja}^{\mathrm{c}}$ far's brother al-Faḍl

67 Al-Ṭabarī, Tārīkh, pp. 4:660-1; Al-Mas ${ }^{\mathrm{c}} \mathrm{u} d \overline{1}$, Murūj al-Dhahab, pp. 3:459-62; For a detailed analysis of the love story and the discussion about love that accompanies it, see Julie Scott Meisami, "Mas' $\bar{u} d \overline{1}$ on Love and the Fall of the Barmakids", Journal of the Royal Asiatic Society (1989), pp. 252-77.

68 Al-Mas $^{\mathrm{c}} \mathrm{u} \mathrm{d} \overline{1}$, Murūj al-Dhahab, 3:465.

69 Sourdel, Vizirat, 1:157.

70 Barthold, W., Sourdel, D. “al-Barāmika or Āl Barmak”, EI², 1033-6. 
b. Yahyā al-Barmakī that offers successful gift exchange as a counterpoint to the far more famous failure. Faḍl, who was known for his generosity, rejected gifts from a subordinate and protégé, Ibrāhīm $b$. Jibrīl. The story is amplified in three ways that emphasize the connection between gift exchange and coercion in social hierarchy. First, at the beginning of the story, Fadil summoned his resentful subordinate and terrified him in doing so. He said, "Don't worry, my power over you prevents me from harming you," and gave him a series of lucrative jobs. Second, at the end of the story, Faḍl refused gifts in his grateful protégé's house, and said, "I didn't come here to plunder you," implying that he could if he wanted to. Finally, before leaving, Faḍl accepted a Sijistānī whip from the protégé, who had held a lucrative position in Sijistān, and said, "This is one of the pieces of equipment used by [noble] cavalrymen" The choice of the whip alludes to his power over his protégé. 71

These features of the story amplify Faḍl's generosity, and they also contrast with Hārūn's treatment of Ja' far. Faḍl's power prevented him from harming his protégé, but Hārūn's power did not prevent him from harming $\mathrm{Ja}^{\mathrm{c}}$ far. Faḍl explained to his protégé that he did not come to plunder him, and Hārūn did plunder $\mathrm{Ja}^{\mathrm{c}}$ far. Faḍl accepted the gift of a whip, which evokes coercion, but the whip is, as Fadll observes, the equipment for noble men. Hārūn was anything but noble in his treatment of $\mathrm{Ja}^{\mathrm{c}}$ far. The rhetorical focal points in this gift exchange story are about Faḍl's nobility toward Ibrāhīm b. Jibrīl even after he was resentful. In contrast, the legend of the downfall is about Hārūn's violence toward $\mathrm{Ja}^{\mathrm{c}}$ far even though $\mathrm{Ja}^{\mathrm{c}}$ far was not resentful. The counterpoint between the two gift exchange stories implies that the failure in the case of Hārūn and $\mathrm{Ja}^{\mathrm{c}}$ far was not inevitable, and it did not have to happen that way.

Like the Barmakid crisis, the assassination of the caliph alMutawakkil and his minister al-Fath b. Khāqān in 247/861, committed by Turkish generals with the help of one of the caliph's sons, turned into a legendary theme. ${ }^{72}$ If the Barmakid theme addresses the relationship between the administrators of the empire and the executive, the Mutawakkil theme addresses the issue of the relationship between the

71 Al-Khālidiyyān, Tuhaf, pp. 147-48.

72 On the development of historiography about the event in conjunction with alBuhturī, see Samer Mahdy Ali, "Singing Samarra (861-956): Poetry and the Burgeoning of Historiography upon the Murder of al-Mutawakkil," Journal of Arabic and Islamic Studies 6 (2005-6). 
military and civilian authority. In stories, both themes are about relationships that break down. The following gift exchange story about the caliph al-Mutawakkil and his minister ' ${ }^{\mathrm{C}}$ Ubayd Allāh b. Yahyā b. Khāqān appears in the second of the two extant monographic compilations on gift exchange, an anonymous work that was probably written by a Fatimid official in the eleventh century in Egypt. In this story, the circulation of a gift of the finest aloe perfume in the world is an indirect retelling of the assassination and an interpretation of its significance.

Al-Mutawakkil set the stage for the conflict that led to the assassination that lurks in the background of this gift exchange story. He was appointed caliph following his brother's death by a committee consisting of a minister, a judge, and two Turkish generals. He then deposed the minister, the judge, and one of the generals. He appointed the ministers ${ }^{c}$ Ubayd Allāh b. Yahyyā b. Khāqān and al-Fatḥ b. Khāqān and put his sons in charge of provinces that had been held by Turkish generals. ${ }^{73}$ Al-Mutawakkil recruited a new army, established a new capital in Iraq, and changed the theological policy of the empire. His approach to dealing with the military alienated him from most of the powerful Turkish generals, and he arranged to take land from one general and give it to his minister Fath. ${ }^{74}$ Likewise, his approach to dealing with his son and first choice for heir, al-Muntașir, undermined their relationship, especially his decision, on the last Friday of Ramadan $247 / 861$, to not lead the congregational prayer himself and instead to have al-Muntașir do it, and then his change of plans to have his other son al-Muc tazz lead the prayer. ${ }^{75}$ The situation was probably exacerbated by al-Mutawakkil's own ministers, who tended to favor al-Muc tazz over alMuntașir. ${ }^{76}$ A group of Turkish generals and the caliph's son alMuntașir had al-Mutawakkil and his minister al-Fatḥ b. Khāqān assassinated in his palace gathering. ${ }^{c}$ Ubayd Allāh was working in his office at the palace. He found the exits locked and had the door to the

73 Modern sources disagree about whether ' ${ }^{~ U b a y d ~ A l l a ̄ h ~ b . ~ Y a h y a ̄ ~ b . ~ K h a ̄ q a ̄ n ~}$ was al-Fatḥ’s nephew (Kennedy, Prophet; Al-Buhturī, Dīwān, 1:516).

74 Al-Ṭabarīi, Tärīkh, 5:334.

75 Ibid. 5:334.

76 See Kennedy, Prophet, p. 171. Why the caliph started to turn away from alMuntașir is not clear. Tayeb al-Hibri, Reinterpreting Islamic Historiography: Hārūn al-Rashīd and the Narrative of the 'Abbāsid Caliphate (Cambridge: Cambridge University Press, 1999), p. 188. 
river bank broken so that he could escape in a small boat. ${ }^{77}$ He went into exile after the assassination but was later reappointed. During the nine years of disorder, four caliphs reigned, three of whom were killed. ${ }^{78}$ The assassination and its aftermath loom in the background of the gift exchange story. The story leads us away from the crisis (all the way to India) to the values of material pleasure, refined manners, and mercantile exchange, but keeps us thinking about the crisis.

This gift exchange story about the best aloe incense in the world is preceded by a straightforward notice that brings the gift to Baghdad. On the occasion of the marriage of his daughter Būrān to the caliph al$\mathrm{Ma}^{\circ}$ mūn in the year 210/825, an Indian king gave gifts to the minister alHasan b. Sahl that included a basket of women's toiletries, including Indian aloe the likes of which had never been encountered before. ${ }^{79}$ In the story that follows this notice, ${ }^{\mathrm{c}} \mathrm{Al} \overline{\mathrm{i}} \mathrm{b}$. al-Munajjim relates the main story:

One night, we were with al-Mutawakkil ${ }^{c}$ alā Allāh. ${ }^{c}$ Ubayd Allāh b. alHasan b. Sahl was with us.He was a refined and elegant person who had experience with people and had witnessed the best of them. Al-Mutawakkil had had a cupping treatment that day, and was weakened, so the doctors instructed him to use good quality, fresh aloe incense, and he did that. Everyone who was present in the gathering swore that they had never ever smelled the likes of that aloe incense. ${ }^{~ ' U b a y d ~ A l l a ̄ h ~ b . ~ a l-H a s a n ~ b . ~ S a h l ~}$ said, "That's from the aloe incense that the king of India gave to my father for the wedding of my sister Būrān to al-Ma ${ }^{\supset}$ mūn." Al-Mutawakkil accused him of lying, and called for the small chest from which the piece of aloe incense had been taken. Less than one awqiya ${ }^{80}$ of the aloe was found, along with a letter in which was written: "This aloe is a gift from the king

77 Al-Ṭabarī, Tārīkh, 5:337.

78 Kennedy, Prophet, p. 171; Al-Ṭabarī, Tārīkh, 5:478; Al-Ya ${ }^{\mathrm{c}} \mathrm{qu} \overline{\mathrm{b}}$, Tārīkh $a l-Y a^{c} q \bar{u} b \bar{\imath}, 2$ vols. (Beirut, 1960/1379), 2:507. In an analysis of two contradictory poems by al-Buhturī on the occasion of the assassination of the caliph al-Mutawakkil, Samer Ali suggests that these poems may be about the destruction of one order for the sake of a new one. See Samer M. Ali, "Praise for Murder? Two Odes by al-Buhturī Surrounding an Abbasid Patricide" in Beatrice Gruendler and Louise Marlow, eds., Writers and Rulers: Perspectives on Their Relationship from Abbasid to Safavid Times (Wiesbaden, 2004), pp. $1-38$ ( p. 30).

79 Al-Dhakhāoir, p. 32.

80 Less than one ounce according to Qaddūmī, see Book of Gifts and Rarities, p. 81 . 
of India to al-Hasan b. Sahl for the wedding of Būrān to al-Ma ${ }^{3}$ mūn.” AlMutawakkil was embarrassed that he had called "Ubayd Allāh a liar and ordered a gift for him. He summoned his minister ${ }^{\mathrm{C}}$ Ubayd Allāh b. Yahyā b. Khāqān and said, "Get a reliable man from among your friends immediately, give him a thousand gold coins for expenses, and have him carry with him gifts in the amount of ten thousand gold coins that cannot be found in India, and tell the messenger to inform the king of India: 'We do not want any recompense for this except whatever he has of aloe perfume'." The messenger executed his task, and returned to Samarra the night that al-Mutawakkil was killed. He held on tight to what he brought of aloe perfume until al-Muctamid ${ }^{\mathrm{c}}$ alā Allāh occupied the caliphate, and ordered the return of ${ }^{c}$ Ubayd Allāh b. Yahyyā b. Khāqān to his position as minister.

The man said, "When cUbayd Allāh b. Yahyyā b. Khāqān returned to the position of minister, I went to see him and when he looked at me he said, 'You are our messenger to the king of India?' I said, 'Yes, I left Samarra to do what you ordered, and I entered Baghdad, and I had carried with me three hundred bottles (khumāsiyas) of wine from Quțabbul. ${ }^{81}$ When the sea water became salty for me, I started mixing it with that wine. So I arrived in India after I had drunk a hundred khumassiyas. I went to see the king and turned over the gift to him and he was pleased by it. I told him about the aloe wood for which I had come. He said, 'That is something that my father sent, and by God I have none in my treasuries except for a hundred manās, so take half and leave half.' I kept cajoling him until he allowed me to take 150 ratls. Then he had me attend his meal. When we ate, they brought nārjīl wine, and I said to him, 'I don't drink this.' I brought out some of the wine from Qutrabbul that I had carried with me and when he saw it, smelled it and tasted it, he said 'What is this?' I said, 'Grape juice.' He said, 'Do you die [become intoxicated] if you drink it?' I said, 'Yes.' He said, 'Because you mix it strong and stay up late drinking it.' He said, 'So I gave him a hundred khumāsiyas, and he ordered for me a hundred thousand silver coins, clothes, perfume and other things like that for me. And I departed and drank the rest of what I had on the way, and I reached Samarra when what happened to al-Mutawakkil had happened, and here is the aloe wood that I saved." "Ubayd Allāh said to him, "All that you took is yours with blessings except the aloe wood. Bring it to me unopened.' And he did that, and 'Ubayd Allāh took it all. And people used to describe the perfume of its scent to each other. And it was that aloe incense that he used to burn, nothing else. ${ }^{82}$

81 A village near Baghdad known for its wine (Yāqūt, $M u^{c}$ jam al-Buldān, 4:371).

82 Al-Dhakhäir, pp. 32-5. 
In this gift exchange story, the manners of gift exchange intersect with the moral problems of coercion and conflict. These moral problems are exemplified by the contrast between the first and second theft of the aloe. The theft in the first half of the story, before the crisis, is accidental. It is committed by the caliph who is acting on doctor's orders and not feeling well. 'Ubayd Allāh b. al-Hasan b. Sahl, who is described as both elegant and experienced, does the right thing by sticking up for his father, and politely calling al-Mutawakkil's attention to the wedding gift. The social engagement of gift exchange that is implied by the wedding gift is briefly undermined when al-Mutawakkil calls ${ }^{c}$ Ubayd Allāh b. al-Hasan b. Sahl a liar. However, thanks to the written note, al-Mutawakkil restores the legacy of the gift and its symbolic meaning of harmony between the royal family and its ministers. The caliph's immediate and costly effort to right the mistake is commensurate with the material value of the amazing perfume and its symbolic value of harmony between the rulers and their ministers.

The theft in the second half of the story, after the crisis, is purposeful. ${ }^{c}$ Ubayd Allāh b. Yahyāa b. Khāqān tells the messenger to help himself to the other gifts that he was given but bring the aloe unopened. In the second theft, nobody sticks up for al-Mutawakkil or the legacy of the gift. Instead of a written note, there is the tacit knowledge, of the minister, the messenger, the people who continue to praise the perfume, and the audience, that the perfume has been confiscated.

The original wedding gift signifies harmony between the royal family and their ministers, and the executive and the administration in general, in conjunction with transnational mercantile harmony between the empire based in Iraq and India. ${ }^{83}$ Harmony between the executive and the administration, and between the Abbasids and India, implies good government that is rooted in sound management of the military and regional resources, as well as a flourishing economy that also yields prosperity through trade. In the second theft, the legacy of the gift is compromised. The stolen gift now signifies betrayal and echoes the assassination. The luxury of the gift corresponds to the value of marriage

83 "Although the devastation wrought by the Mongol conquest of Iraq in the thirteenth century makes it difficult to trace the impact of these eastern imports on the artistic production of the Abbasid heartlands, the cultural flows of the period were clearly multidirectional, suggesting that the relationship between center and periphery was considerably more complex than has usually been assumed" (Finbarr B. Flood, Objects of Translation: Material Culture and Medieval “Hindu-Muslim” Encounter (Princeton, 2009), pp. 15-6). 
as a figure of political harmony, and it is incongruous with the crisis of assassination and betrayal.

The aloe is about mercantile harmony, in which the Abbasid elite can be as delighted with the aloe as the Indian king is with the wine. The messenger's excessive enjoyment of the wine all the way to India and back contributes to the theme of delighful cruise. This utopia of mercantile delights is at odds with the violence of the assassination that occurs on the night of the messenger's return, and with the political unrest that follows the assassination, during which the messenger hides his stash of perfume until ' Ubayd Allāh b. Yahyā b. Khāqān returns to power, since he is the one who sent him to India on al-Mutawakkil's behalf. Finally, the gift exchange as mercantile delight is most at odds with the outcome of the trustworthy messenger's mission, when the minister who ordered it on al-Mutawakkil's behalf, for the sake of the legacy of the married couple as a figure of political harmony, not only confiscates the aloe, but also ostentatiously consumes it. While the wine circulates outward into the world in a display of trade relations, the aloe spirals inward, into the political turmoil at the heart of the Abbasid Empire, and finally into the hands of the minister who betrays his late ruler and patron, and the legacy of the married couple.

Rhetorical focal points help to define the significance of the aloe. The discovery of the note uncovers the first theft, in contrast to the silence in response to the second theft. The first comment by the people who experience the fragrance is about manners, the sociable appreciation of sensory pleasure and fine things. The second comment by the people, in which they describe the aloe to each other, occurs in the context of the second theft and seems to reverberate in the silence about the theft and the assassination. Like Hārūn's traumatic repetition in his re-reading of the offending poem, the comment about people continuing to describe the aloe to each other resembles a traumatic repetition. The pleasant experience of the aloe takes the place of the difficult experience of assassination, political turmoil, and betrayal. And like Hārūn's traumatic repetition, the repetition that is implied in the comment about people describing the aloe to each other opens out onto the continuous retelling of stories about the political crisis.

Another example featuring a trip to India and designated as story about gifts shows how the strangeness and delights of India are used to explore danger in Arabic-speaking political centers. According to this story, the scion of the Barmakid family, Barmak, used to visit Indian kings, perhaps a reflection of the fact that the Barmakids supported the integration of Indian science and culture in Arabic scholarship. At the 
court of an Indian king, Barmak ate his fill and then the king ordered him to eat more. ${ }^{84}$ When he said that he was done, the king had a baton brought in to threaten him repeatedly, so that Barmak felt that he has done the wrong thing and overate. The feeling of doing the wrong thing emphasizes the strangeness of the place for Barmak, while overeating is a distortion of material pleasure. After this forced overindulgence, Barmak looked at an official's ruby and the official threw it in the water, so that Barmak again felt that he had done the wrong thing, and told this to the official when he was asked about why he looked so dejected. The official said that it was no problem, and displayed a silver fish that had swallowed the ruby. Once again, strangeness and material delight go together. However, this discomfort about doing the wrong thing while in India is nugatory in comparison with Barmak's discomfort at his reception by the Umayyad caliph Hishām. He related his adventures to him, and Hishām ordered him to procure some fine food. Soon afterward, Barmak was summoned as is when he had just taken off his clothes to wash up. This sign of trouble resembles ' Umāra's encounter with Abū 1- ${ }^{\mathrm{c}} \mathrm{Abbās}$ and Umm Salama in the story discussed above. Barmak was sent back home, got cleaned up, and then returned to Hishām to find out what was wrong. Hishām explained that he had a ruby that changes color if someone possessing poison came to see him. He said that the ruby changed color when Barmak met with him. Apparently Barmak had been working with (perhaps using?) opium while filling the caliph's order. As in the aloe perfume story, in this story, India is strange but safe, while the imperial center is familiar but dangerous. Barmak feels that he did the wrong thing when he stared at the jewel in India, but it is no problem; he does nothing wrong in Damascus, but the caliph discovers from his magic jewel that there is something wrong with Barmak. The story about Barmak links Muslim West Asia and India through the jewel, just as the story about alMutwakkil links the two locations through the aloe perfume. In both stories the point of the link is to heighten the contrast.

One sequence of signs culminates with a gift exchange that leads into the assassination, and helps to explain the aloe story. Al-Buhturī is the intermediary. In the first sign, the people in the caliph's gathering were discussing the arrogance of kings, and al-Mutawakkil withdrew from the discussion, turned in the direction of prayer, put dirt on his head out of humility, and said that he would return to earth so it was right for him to

84 Al-Ghuzūlī, Mațālic ${ }^{c}$ pp. 453-4. 
be modest, not arrogant. ${ }^{85}$ In the aloe perfume story, it is alMutawakkil's power which leads him to appropriate the gift and his arrogance that leads him to call ${ }^{~}$ Ubayd Allāh b. al-Ḥasan b. Sahl a liar when he objects. In contrast, it is his humility that makes him go to great lengths to replace the stolen aloe. The religious theme serves as an ethical backdrop for the problem of the assassination. In the second sign, al-Mutawakkil was enjoying a song and suddenly said to Fath, "We're the only ones left to listen!" and started crying. ${ }^{86}$ Just as pleasant music contrasts with impending doom in this story, the aloe perfume story juxtaposes the delight in the incense with the assassination and the problematic confiscation of the aloe by ${ }^{c}$ Ubayd Allāh b. Yahyā. The series culminates with the third sign. Qabịna gave al-Mutawakkil a fine garment and he tore it, saying, "Let no one wear it after me". $87 \mathrm{Al}$ Buhturī commented, "I said to myself, we belong to God and to Him we return [what one says when a death occurs], it's all over now". ${ }^{88}$ The tearing of the robe may echo the tearing of collars in mourning. The contradiction between the luxurious robe and the act of tearing it out of anxiety about the future is amplified after the assassination takes place, in one version of the burial. Qabịha wrapped al-Mutawakkil in the torn robe as a shroud. ${ }^{89}$ The connection of the same person giving the robe as a gift and wrapping al-Mutawakkil in it as a shroud, and their intimate relationship, reinforce the theme of pleasure joined to catastrophe. In this story as in the aloe perfume story, gift exchange is linked to marriage, and the combined pleasure offers a counterpoint of pleasure to catastrophe.

The commentary on the assassination in poetry by al-Buhturi contributes to the expanding historiography about it. ${ }^{90}$ This expansion of historiography complements the aloe perfume story, which views the event from a marginal point of view. Al-Mas ${ }^{\mathrm{c}} \overline{\mathrm{d}} \overline{\mathrm{i}}$ concludes his assassination stories by explaining, "And there are other stories of how al-Mutawakkil was killed, and this is what we have chosen in this context, for it had the best wording and the most accessible style..." and

\footnotetext{
85 Al-Mas $^{\mathrm{c}} \mathrm{u} \mathrm{d} \overline{1}$, Murūj al-Dhahab, 4:138.

86 Ibid. 4:138.

87 For a detailed discussion of this gift, see Ali, "Singing Samarra".

88 Al-Mas $^{\mathrm{c}} \overline{\mathrm{u}} \mathrm{d} \overline{1}$, Murūj al-Dhahab, 4:138.

89 Ibid. 4:139.

90 Ali, "Singing Samarra".
} 
noting that there are other stories about the event. ${ }^{91}$ The aloe perfume story does not appear in major historical accounts of al-Mutawakkil perhaps it is one of those other stories.

In these longer gift exchange stories, about Fayḍ and Ahmad, Umm Salama and ${ }^{\mathrm{c}}$ Umāra, Hārūn and $\mathrm{Ja}^{\mathrm{c}}$ far, and al-Mutawakkil and ${ }^{\mathrm{C}}$ Ubayd Allāh b. Yahyā, writers investigate the emotional experience that weaves together material delights and political crisis. These stories relinquish moral authority in favor of manners, while also commenting on much more serious business.

Gift exchange stories may offer an indirect commentary on social issues through the themes of the wrong rhetoric, relationship problems, social tensions, and political crisis. They take a step away from serious social issues to offer an oblique angle for interpretation of them. The incongruence of fine gifts and tense situations, and the use of rhetorical focal points, silence, and communication at a distance provide implied perspectives on the inner life and emotional experiences of characters. Families of texts about a particular character amplify and modify these perspectives on inner life and political crisis. In $a d a b$ literature in general, and in gift exchange stories in particular, major historical events and serious moral inquiry undergo a kind of "ababification" that makes them less serious, though no less significant. Manners become a kind of mannerism, feeding off of more serious discourse, and also feeding back into it.

91 Al-Mas ${ }^{\mathrm{c} u ̄ d} \overline{1}$, Murūj al-Dhahab, 4:139. 